\title{
THERMAL COMFORT, ADAPTABILITY AND SUSTAINABILITY OF VERNACULAR SINGLE FAMILY HOUSES IN LIBYA
}

\author{
Abdrahman Shahran, Darko Reba, Milena Krklješ
}

Preliminary communication

Traditional and vernacular housing was developed in close relation between the functional needs of the occupants, the culture, climate, and other aspects of the living and built environment. Over the course of the last decades, most developing countries, including Libya, have experienced a rapid economic growth and increase in population, leading to the increase in construction of contemporary single family houses influenced by western models. The paper analyses aspects of thermal comfort in traditional single family houses in mountain (city of Gharyan) and desert regions (old city of Ghadames) in Libya with an aim to investigate advantages of the vernacular concepts in contemporary design. The study will establish valorisation criteria by researching structures, materials, internal arrangement, roof, openings and other aspects that influence sustainability. The results will be used in the fields of architecture, urban design and building industry in Libya, since the knowledge of traditional concepts and elements sustained through a long period of time will be valuable in building healthy homes and saving non-renewable energy in contemporary structures.

Keywords: climate; materials; sustainability; thermal comfort; tradition; vernacular architecture

Toplotna udobnost, prilagodljivost i održivost vernakularnih obiteljskih kuća u Libiji

Prethodno priopćenje

Tradicionalna i vernakularna kuća razvijena je u uskoj vezi između funkcionalne potrebe stanara, kulturnih, klimatskih i drugih aspekata života $\mathrm{i}$ izgrađenog okoliša. Tijekom posljednjih desetljeća, većina zemalja u razvoju, uključujući Libiju, doživjela je brzi gospodarski rast i povećanje populacije, što je dovelo do povećanja u izgradnji suvremenih obiteljskih kuća pod utjecajem zapadnih modela. U radu se analiziraju aspekti toplotne udobnosti u tradicionalnoj obiteljskoj kući u planini (grad Gharyan) i pustinjskom području (stari grad Ghadames) u Libiji, s ciljem da se istraže prednosti vernakularnog koncepta u suvremenom dizajnu. Studija će utvrditi kriterije vrednovanja kroz istraživanje konststrukcije, materijala, unutarnjeg uređenja, krova, otvora i drugih aspekata koji utječu na održivost. Rezultati će se koristiti u području arhitekture, urbanog dizajna i građevinske industrije u Libiji, jer je poznavanje tradicionalnih koncepata i elemenata koji su korišteni kroz dugo vremensko razdoblje, dragocjeno u izgradnji zdravih kuća i štednji neobnovljive energije u suvremenim konstrukcijama.

Ključneriječi: klima; materijali; održivost; toplotna udobnost; tradicija; vernakularna arhitektura

\section{Introduction}

In oil-rich countries, many contemporary housing projects encourage the use of expensive imported materials, and because of that, such countries have become dependent on the import of building materials and infrastructure components. Additionally, the buildings constructed using those materials are not suitable for the climatic conditions of the region. Libya, like most developing countries, has experienced a rapid growth in the construction sector during the last thirty years. Unfortunately, this growth was only in favour of "modern" construction, which gave rise to a large number of uniform-type reinforced concrete structures being built all over the country, with practically no regard for the conditions prevailing in their vicinity, both climatic and cultural. This resulted in not only uncomfortable and energy-consuming buildings, but also in severance of ties with the historical past and culture of local people.

On the other side, vernacular single family houses designate the common, non-scientific pattern of residence. It is an indigenous building style using local materials, traditional construction methods and ornament, especially as distinguished from academic or historical architectural styles. Its architectural designs reflect the natural environment. Flat roofs or no roofs at all are sensible choices in regions with low rainfall as in desert regions, in Libya. The main issue in vernacular architecture is the lack of insulating materials, therefore traditional architecture and construction is characterized by high infiltration rates, small windows and doors that are often mere pieces of fabric. Houses are incorporated into the surrounding environment through the necessary use of local, natural materials for construction alongside the aesthetic role in architectural composition. At the same time city's development, both in the sense of adaptation of old cities, or building the new ones, has its functional, social and morphological peculiarities [1] that are strongly related to the first Phoenician settlements created in Libya, to the tradition of ancient Roman and Greek houses whose remains were found during excavation in 1940 s, as well as influences from the most significant changes that occurred when Muslim Arabs conquered Libya in $642 \mathrm{AD}$, bringing new religion, culture, language and certain pattern of living which became deeply rooted and which has characterised the country ever since [2]. After Italian invasion in 1911, the Libyan people have inherited many methods of house construction, depending upon the local climate and meaningful characteristics in form and architectural elements, which is specifically related to residential architecture $[3 \div 6]$.

Beside climate conditions that influence house structure, plot optimization is also significant for living commodity in a single family house [7], especially in desert area, as well as house shapes and spatial organization in settlements with their urban growth in general [8]. Not many research studies were conducted to investigate outdoors thermal comfort in urban environments, very rarely focusing on the role of urban geometry and usually based only on numerical modelling $[9,10]$. 
This study was undertaken to investigate some of the significant factors underlying the apparent success of the construction patterns that were dominant in Libya's past. The main advantage of the traditional and vernacular architecture was their friendliness to environment by way of using local building materials, as well as by their design, which not only respected, but also took advantage of the governing climatic conditions in the area. Various researches have been performed about living conditions in hot areas [11], with different building materials (stone and mud) [12], resulting with conclusions about thermal mass as an essential strategy for indoor climate control in hot dry climates in a wide variety of building types [13]. Suggestions for improvements of living conditions in hotdry climates mostly include use of appropriate housing design $[14 \div 17]$.

Many types of single family houses in Libya were researched to establish relations and to analyse connections between traditional systems and their potential usage in contemporary construction, through their evaluation. It is presumed that various natural effects have an important impact on the design of single family housing in Libya, such as the thermal comfort of home, which is considered as one of the existing problems in the contemporary homes and must be overcome through different solutions.

A research effort is therefore necessary to contribute to the understanding of these distinctive adaptable residential typologies. The research employed qualitative case study approach to examine the basic styles used by traditional builders/architects. The key research concerns geared at enquiring the characteristics of traditional Arab house. Others are the traditional Arab house physical and social adaptability features to the environment.

\section{Research objectives}

Aspects of thermal comfort and adaptability headline of single family housing in Libya are the topic, which demands very broad and detailed researches and studies. An important issue is that the world's deserts have expanded from a considerable $22 \%$ of the world's potentially arable lands [18] to over $30 \%$ [19]. The investigation of the differences between old and new forms of housing construction in different Libya areas from the perspective of the prevailing microclimate is an important element of the full set of studies concerned with a comparison between them. Therefore, the research started with the study describing the problem and scope of the research through direct observations, interviews, and discussions with local people, in the city of Gharyan, and old city of Ghadames.

Research results about the environmental conditions and thermal comfort within two types of buildings, old (traditional) and new (contemporary), conducted in Ghadames oasis in Libya, showed that people have an overall impression of higher standard of thermal comfort in old buildings than in new ones [20], almost the same as research about the possibilities for improvements in the design of new houses to conserve energy and enhance indoor thermal comfort in comparison to the old and traditional one using the importance of architectural features responsible for difference in the thermal performance [21]. There is also important research about influences of urban structure to the thermal comfort in desert cities [22] that confirms the vertical street profile is of prime importance in the resulting thermal sensation, as well as building materials that were also found to play a decisive role. But, there are also researchers that have questioned the climatic effectiveness of traditional solutions $[17,23]$. By measurement of temperature inside of houses during different hours of the day and year, it was possible to compare the thermal comfort in different houses. Furthermore, drawings and photographs were taken to visualise documentation and to create plans and architectural model for these houses, analysing several aspects, such as housing construction, issues of tradition, functions and their relation to sociocultural conditions, as well as structure and materials.

Depending on the purpose, the goal and the conditions relate to the issue of poor adjustment of modern housing to the existing environment in diverse aspects of the topic studied with a view to housing construction in Libya that would make it possible to maintain the continuity and cultural identity of the region. After determination of how different natural influences impact the design of elements in traditional single family housing in Libya, analysis of different types of individual housing in Libya was performed to establish connections between traditional and contemporary elements and systems. All of above-mentioned objectives were related with the investigation towards conclusions how aspects of thermal comfort and adaptability of traditional single family housing can be transformed into contemporary design solutions.

\section{Overview of geographical and weather climate factors of regions in Libya}

In Libya, natural conditions have influenced the built environment to a great extent. It can be observed in the physical structure of buildings, land usage, and distribution of population. About $94 \%$ of the total area of Libya is a desert, most of which is considered to be unproductive. About three-quarters of the population is situated in major urban areas and most of the cultivated land is concentrated in less than $2 \%$ of the country's total area $[24,25]$. The topographic features vary throughout the country and include plains, mountains and the desert. The second topographic characteristic is the mountain area, which is divided into two ranges: the Western mountain (JabelNufusa) in the south of Tripoli, and the Green mountain (Jabel-Akhder) in the northeast of Libya. The former has an average width of $20 \mathrm{~km}$ and the height between 500 and 960 meters. The land is composed of basalt, volcanic rock, limestone and gypsum-marl. Most of the mountain areas are covered with shrub forest consisting of pine and juniper bushes. The third topographic area is the desert. It begins just behind the mountains and extends toward the South, covering more than $90 \%$ of the land area. From the Egyptian border, a wedge of extreme desert extends westward with different soil types consisting of limestone, sand stone, and gypsum [26]. In the desert, there are oases developed far apart from each other in shallow basins and valleys, where ground water reaches the surface. The land rises 
towards the south, reaching $2286 \mathrm{~m}$ at the peak on the border with Chad [27]. The weather in Libya is hot in summer time, some days the temperatures can reach the level of $47{ }^{\circ} \mathrm{C}$ with quite high humidity in most regions, especially in July and August. Winter in this region often brings rain and cold nights, with an average temperature of $10^{\circ} \mathrm{C}$. During spring, an average temperature is from 15 to $30{ }^{\circ} \mathrm{C}$, which took place at the end of spring and the beginning of summer [28].

\section{Criteria for valorisation of single family houses in Libya}

For study of vernacular single family houses, we have established criteria as tools for investigating specific structures in two Libyan regions. Those criteria are not the instrument for designing houses; rather, they are aspects that will help extend the knowledge about interesting systems in the organization and development of housing typology in specific climatic, cultural, technological and social conditions of Libya.

\subsection{Climate of location}

The climatic conditions play a major role in shaping the residential area of house designs in Libya. The climate is clearly one of the prime factors in Libyan society, and one of the most influential elements affecting the shape of buildings. The differences in temperature, winds, and sun intensity are conditions that must be resolved in designing houses in Libya. It is the mainspring for all sensual qualities that add up to a vital tropical architecture. Due to the almost complete absence of cloud screening, the ground receives a great amount of solar radiation by day, while it radiates a great amount of heat out to the atmosphere by night. Therefore, the comfort of people inside buildings in such zones depends largely upon the thermal properties of the walls and the roof.

\subsection{Urban setting}

Libyan population has recently become more urban than rural, which is very influential for the new typology of single family houses. The urban setting and topography of settlements is one of the major factors with an important effect of sustainability. Most settlements in hot climates have developed as houses in clusters more or less connected to each other in order to diminish inappropriate climate influences, or in other similar systems of urban organizations.

\subsection{House organization}

Internal organization of houses, such as courtyard, roof and typology of openings, strongly influence and contribute to the adequate function and thermal comfort of the house in different Libyan environments.

\subsection{Materials and structural systems}

Hot zones characterize the climate of Libya, with a very wide range between day and night temperatures. Following that condition, the best materials are those that do not conduct heat. Due to it, in the vernacular architecture in Libya, builders mostly use simple locally available materials, and they are always focused on the benefits of using them for construction and as a solution to many problems such as pollution, economy, complicated construction, etc. The structural systems are different depending on the region and affordable building materials. Vernacular concepts of structural systems can be inspiring for contemporary houses in many aspects, and it is very important to examine how structures, which were in some cases built 2000 years ago, are very sustainable and still stand today.

\subsection{Thermal comfort}

Using only architectural knowledge and experience and without any additional complex systems traditional builders can obtain a level of comfort which in many places would be sufficient without having to use contemporary energy supplies. Without necessarily increasing the initial investment in the construction, a vernacular house can save a high percentage of energy costs both in heating and in cooling by using passive and purely architectonic elements to collect the nature energy.

\section{A case study of vernacular single family houses in mountainous and desert regions in Libya}

In the paper, two traditional single family houses are analysed in two different cities in the specific geographical and climatic areas represented by Gharyan in the mountainous region, and Ghadames in the desert. This study has been undertaken in two cities to understand and evaluate some of the significant factors in terms of architectural design and construction, materials, and inside facilities as parts of the dwelling, as well as internal and external appearance that contribute to aspects of thermal comfort and adaptability. With respect to design characteristics, greater attention is put on micro climatic aspects, such as thermal mass and window size, air circulation within the house, dimension of elements, wall thicknesses, study of interior and exterior colours, and other important aspects.

\subsection{Mountainous region: field survey in Gharyan}

The city of Gharyan is located south of Tripoli, about $90 \mathrm{~km}$, on a mountain chain called "The western mountain". The city has a population of about 161000 inhabitants, and has the area of approximately $4660 \mathrm{~km}^{2}$.

The underground house is one of the dwelling types used by the ancient civilizations in many parts of the world. It is mainly found in Italy, France and in the west part of the North African coast and China.

\subsubsection{Climate}

The climate of Gharyan is cold and rainy in winter, with an average temperature of $10^{\circ} \mathrm{C}$, and hot and dry in summer with an average temperature of $35^{\circ} \mathrm{C}$. This leads people to utilize the mass effect strategy, the warmth of soil in winter and its coldness in summer. 


\subsubsection{Urban setting}

The location of the mountain Gharyan is on the south of Tripoli at $32^{\circ} 11^{\prime} \mathrm{N}, 13^{\circ} 00^{\prime} \mathrm{E}$ and its altitude is about $1000 \mathrm{~m}$ above the sea level. There were about 1300 houses in this location in 1666 approximately. Most of those houses in the mountain area have rural characteristics and appearance and are usually positioned and arranged in a compact grouping, which means that relatives usually live together, or live as near neighbours (Fig. 1). The centre of settlement during the early centuries of Islam, were the mosque and storehouse as the focal points of the community, and the layout of settlements reflected their importance by placing these buildings at the centre and constructing houses, which were usually adapted to the climatic conditions, around them [29]. For the urban setting the significant factor in Gharyan were two types of traditional dwellings, both of them well suited to the climate that has high diurnal and annual temperature changes with little rainfall. The first type (Aboskefa) is completely underground without any elevation, while the second one (Al-Feseal) is partially underground with some elevation. Beside the fact that underground houses have many advantages, since they are very inexpensive to build, and do not require much material and that compared with above-ground dwellings they are warm in winter and cool in summer, as a result of the stability of temperature underground, they also have significant influence on urban setting of the settlements because their own character and architectural features defines specific spatial relations that provide a great deal of privacy for the large family.

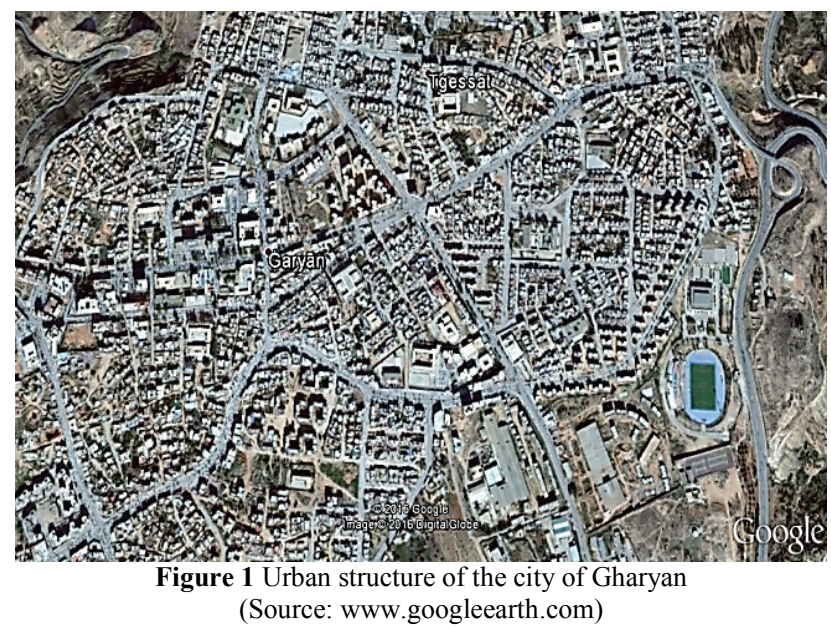

\subsubsection{Materials and structural systems}

The house is carved in limestone, meaning that it does not need construction material and that everything is found on the location or in vicinity. In general, minimum construction material is used in terms of a unit in the entrance area. Some of the advantages in this construction include resistance to severe weather, an unobtrusive presence in the surrounding landscape, and a nearly constant interior temperature due to natural insulating properties of the surrounding earth. The greatest appeal for most is the energy efficiency and environmental friendliness of the underground dwellings. Structural system in underground dwelling is based on a solid system. Internal spaces are formed after digging a central courtyard with all rocky and clay layers. After that, entrances into internal arrangements are dug, while the rooms are shaped with the solid rocky layer. After a layer of soil, which is $2 \div 3 \mathrm{~m}$ thick, a rocky solid layer is used to provide the base for the coherent clay layer.

\subsubsection{House organization}

Troglodytes are made as caves or cubic holes dug vertically into the relatively soft ground. These holes/caves used to be dug manually by specialized workers (Fig. 2). Because of the hot climate through summer and the freezing winter nights in the mountains of Gharyan, where normal ventilation and isolation does not manage to keep the heat out in summer, or within during winters in contemporary houses, the Troglodytes possess the capability of providing good heat isolation during the hot summers and cold winters. In other words, Troglodytes provide a comfortable climate for their occupants throughout the year [32].

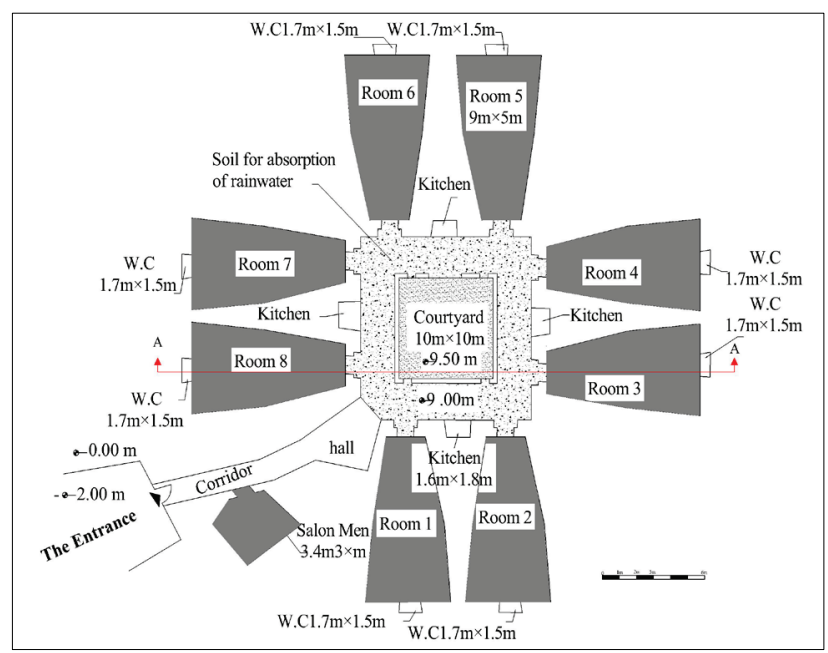

Figure 2 Plan of the house in Gharyan

The underground dwelling consists of eight large rooms, where each room is used as a home for one family. Total area of the house is about $446 \mathrm{~m}^{2}$. The courtyard allows air circulation and sunlight to enter the rooms during the day, and the natural light of the Moon during the night. The house does not lean on any structural element, and therefore there are not any partition walls dividing the internal space.

Bedrooms are dug deep in a shape similar to trapezoid, where the dimensions of the entrance area are about $1.90 \mathrm{~m}$. This is the smallest dimension of the space, and the width of the room expands until it reaches approximately $5 \mathrm{~m}$. The room is divided by curtains into three parts. The first part is a living room, since it is located next to the entrance. The second part is in the middle of the space and it is the children's room. The third part is at the end, and it is planned for a married couple. And, at the very end, there is a bathroom. As it can be noticed, the difference between these three parts is just in the ground level. Each level is elevated $15 \mathrm{~cm}$ from the previous one. The height of the room is approximately $2.30 \mathrm{~m}$ in the middle, as shown in Fig. 3 and 4. 


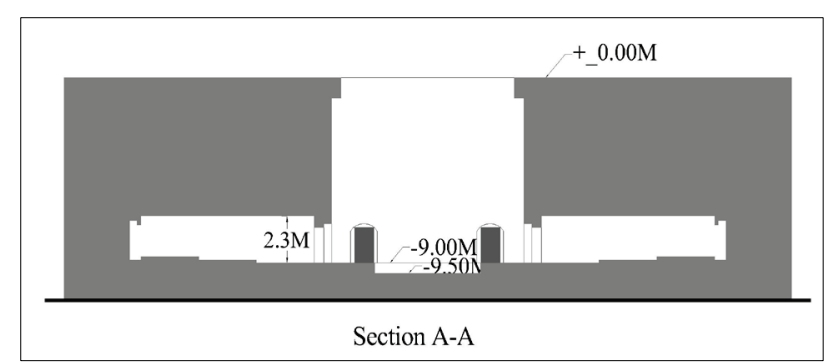

Figure 3 Section (A-A) of the house in Gharyan

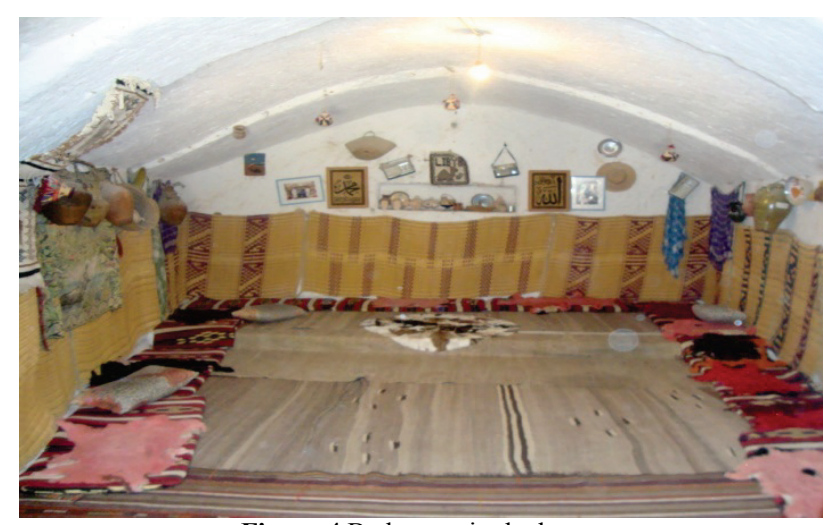

Figure 4 Bedrooms in the house

The courtyard in this house is square-shaped, with dimensions $10 \times 10 \mathrm{~m}$ and the height up to $9.50 \mathrm{~m}$. The courtyard has a number of important functions. First, there is technical function, to arrange movement between rooms and other facilities surrounding it, though not connected to it. Second, it also has a social and cultural function, when inhabitants gather during the evening to listen to legends and stories. Furthermore, it is used for wedding and circumcision celebrations. It contains plants and trees, as shown in Fig. 5, contributing to the positive humidity of the space, and making it look green, which is very important in the mountain region. The courtyard in this house obviously meets the social and environmental needs of its inhabitants. Also, the system of natural ventilation in courtyard has the potential to reduce the energy required for cooling and ventilating underground dwelling while still providing acceptable thermal comfort and indoor air quality.

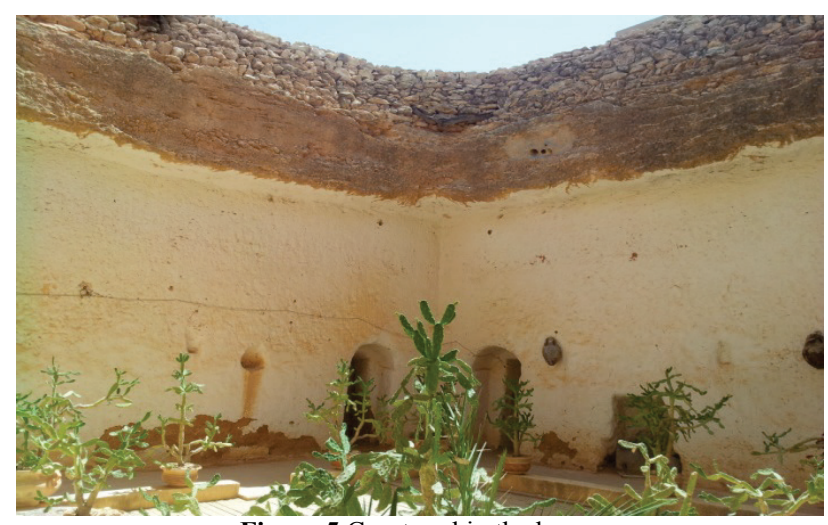

Figure 5 Courtyard in the house

\subsubsection{Thermal comfort}

The mean annual temperature outside is approximately $45{ }^{\circ} \mathrm{C}$. In July, the temperature inside the analysed house is always about $23{ }^{\circ} \mathrm{C}$, while in January the temperature is only $19{ }^{\circ} \mathrm{C}$ inside the house, while outside is approximately $5{ }^{\circ} \mathrm{C}$. The parameters measured in this study were air temperature outdoors and indoors. Figs. 6 and 7 present hourly dry-bulb temperatures measured during January in winter and during July in summer, 2014. Also we conclude from Figs. 6 and 7 that the majority readings of indoor temperature for the traditional house are approximately constant during the day in summer and in winter, and were within the range for human comfort in this zone. That is because of many reasons such as the house was completely dug underground, isolated to a high extent from external environment, made of natural local materials and the house style was appropriate for the local climate.

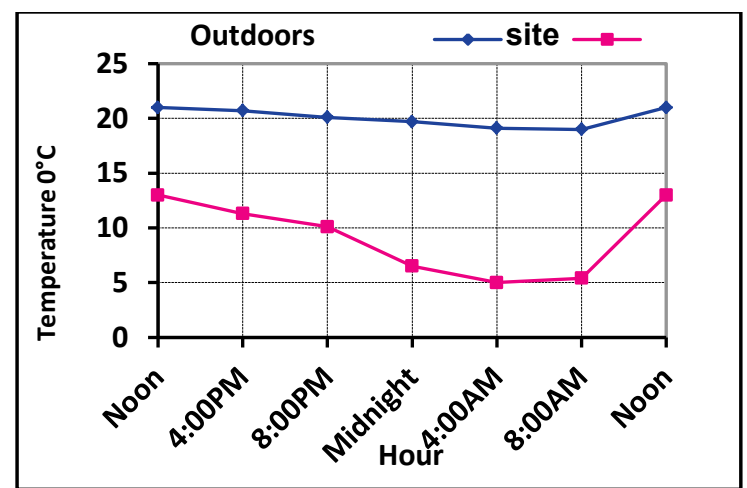

Figure 6 Temperature data for Gharyan during one day in January

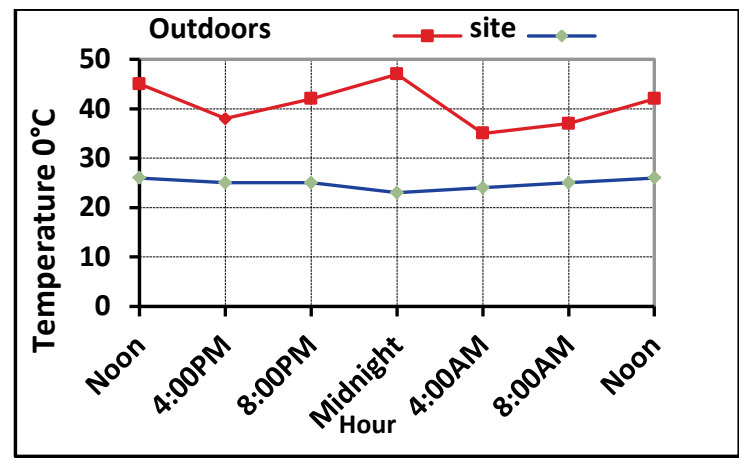

Figure 7 Temperature data for Gharyan during one day in July

\subsection{Desert region: field survey in Ghadames}

City Ghadames is located in the northern part of the African desert, about $650 \mathrm{~km}$ south of the Mediterranean Sea coast and Tripoli, the capital city of Libya. Libya is on the latitude of $30^{\circ} 08^{\prime} \mathrm{N}$ and the longitude of $9^{\circ} 30^{\prime} \mathrm{E}$ [28]. It is located about $300 \mathrm{~m}$ above the sea level and it has a number of sand - hills surrounding it as a crescent from north and west side. Between the Maghreb and the heart of Africa, Ghadames is at the intersection of Libya's border with Tunisia and Algeria [28]. The housing area of Ghadames is about 820 hectares.

This housing zone can be classified into three main categories. Firstly, the traditional houses within the old settlement, which constitute about $11 \%$ of the total residential zone. Secondly, there are scattered houses in the entire settlement, forming about $15 \%$ area. Thirdly, new modern houses have been built recently from concrete, comprising $74 \%$ of the area. The common height of these houses is 2 or 3 floors, surrounded by agriculture land [30]. 


\subsubsection{Climate}

The city of Ghadames has hot days and very cold nights in general. The climate in the city is warm during winter, due to the desert sand. Sunrays, with the sand being warmed quickly and becoming cold equally fast, affect it directly and quickly. In the summer period, the day is unbearably hot, though the night is moderate, fitting and comfortable. The mean maximum temperature for Ghadames, from May to October, is between $35^{\circ} \mathrm{C}$ and up to $48^{\circ} \mathrm{C}[31]$.

\subsubsection{Urban setting}

The old town, with its settlements located down the oasis, built on almost $7 \mathrm{~km}^{2}$ of land, consists of three main neighbourhoods with more than 1300 houses, mosques, markets, public squares, and baths, structured in a highly compact and dense layout (Fig. 8). The traditional architecture of the town is unique in its building form and layout, representing a good pattern of well-sheltered spaces protected from extreme and harsh climate conditions [32]. The period of construction of the analysed house is approximately 3000 years ago. The total house area is about $224 \mathrm{~m}^{2}$. The house is positioned in the densely built old town of Ghadamis, surrounded on its lateral side and the back by walls of similar houses, while the front side is oriented towards the street.

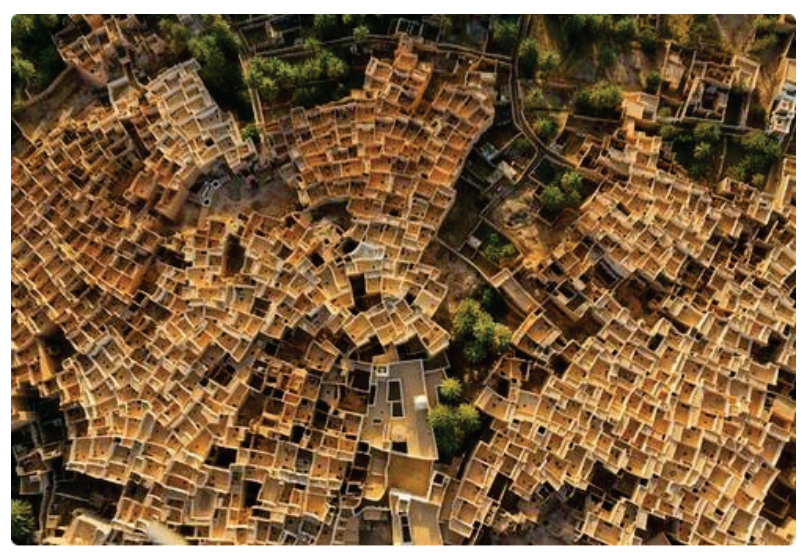

Figure 8 Aerial view of the urban setting in the old town (Source: www.amusingplanet.com/2013/03/the-old-town-ofghadames.html)

The street is known as the "alleyway" and shown in Fig. 9. The alley is a covered space forming narrow passages, which occasionally expand; its width varies from 1.5 to $3 \mathrm{~m}$, depending on the position of the street. The alley is characterized by sharp curves and breakage, these curves are used for ventilation and for converting the strong wind into a gentler breeze, also the alley provides shade for people to rest, meet, and walk comfortably, as it offers a high level of indoor privacy. There are openings in the ceiling of the alley for the purpose of ventilation and for providing light. The distance between each opening is about $15 \mathrm{~m}$, and one of the openings is shown in Fig. 10.

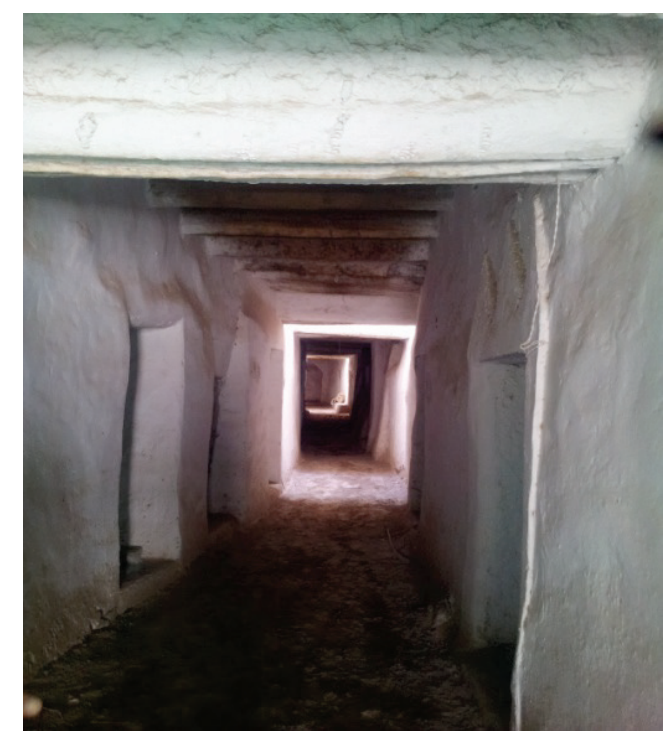

Figure 9 Street or passageway in the old town of Ghadames, called the "alleyway"

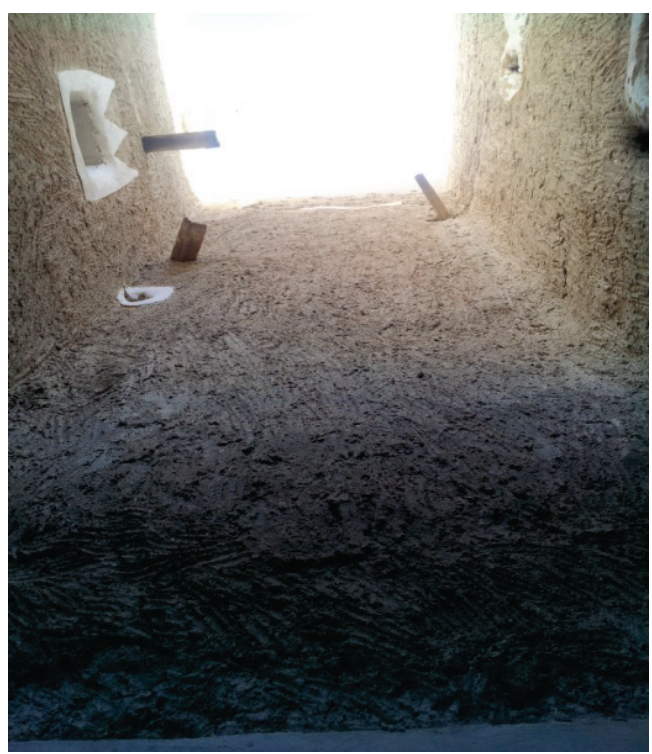

Figure 10 Openings in the ceiling alleys for air circulation

\subsubsection{Materials and structural systems}

For the foundations of the single family house in the desert region of Ghadames, granite stone is used. Bricks made of clay and dried in the sun are used for building walls. Stumps of the palm trees are used for ceiling, and over them, tiny limestone and clay are laid. Stumps are also used for trusses and beams over windows and doors. All materials are natural and founded in the vicinity of the city. The structural system leans on load-bearing walls interconnected between the houses. This kind of structure makes those houses firmly connected to each other in order to increase the support and provide the isolation from the external environment. The outer and inner walls are wide at the bottom and the thickness is reduced while the height increases. Their width ranges from 40 to $70 \mathrm{~cm}$, this is adequate for thermal comfort inside of house (Fig. 11). The ceiling height reaches up to $2.50 \mathrm{~m}$ in the rooms, while the height in the storage units is $1.60 \mathrm{~m}$. 


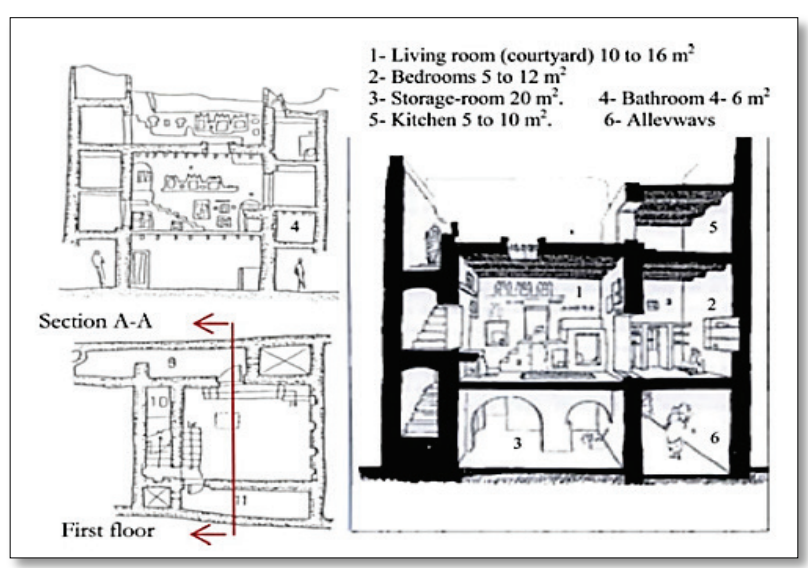

Figure 11 Plan and sections of the old house in Ghadames [32]

The roof is a significant element in vernacular house in Ghadames, it plays an important role in the life of a family since it is the only outer space of the house. It is used as a kitchen; a place for cooking and women's daily activities and it has a different location than in a traditional house in Tripoli. This kitchen is placed on the roof to increase mutual shading and also to dispose heat and smoke outside the house. There are passageways on the roof especially for women. Roof can be used as a space for children to play, as well as for sitting and sleeping at night during the summer, as shown in Fig. 12. High exterior walls provide privacy and protection from hot winds and dust.

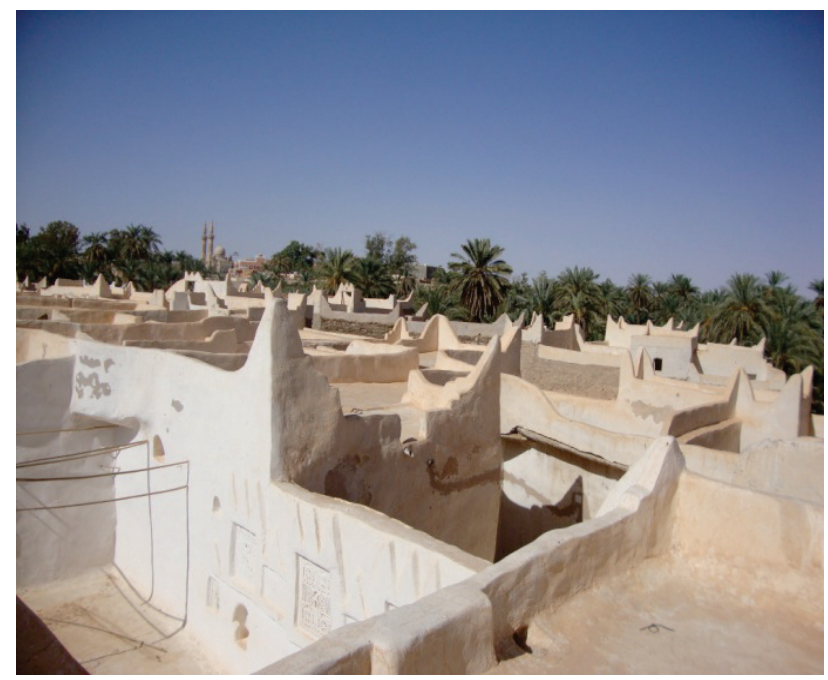

Figure 12 Roof for sitting and sleeping at night during summer

This house does not have any windows on the external walls, and this is interesting example in the analysis of traditional houses in Libya. There is an opening in the ceiling of the living room that is used for providing natural light, with the help of mirrors placed on the walls of the same room, all the way to the salon for men. Those openings are small and rectangular in shape, as shown in Figs. 13 and 14. They can also be used for circulation of fresh air, which will substitute the air from the interior that is not adequate for daily use. Furthermore, they are used during night for eliminating heat accumulated during the day, until the sunset, in the interior. This is the manner in which interior premises and walls cool down in order to be pleasant during the following day. The above-mentioned hole in the roof is normally closed during winter.

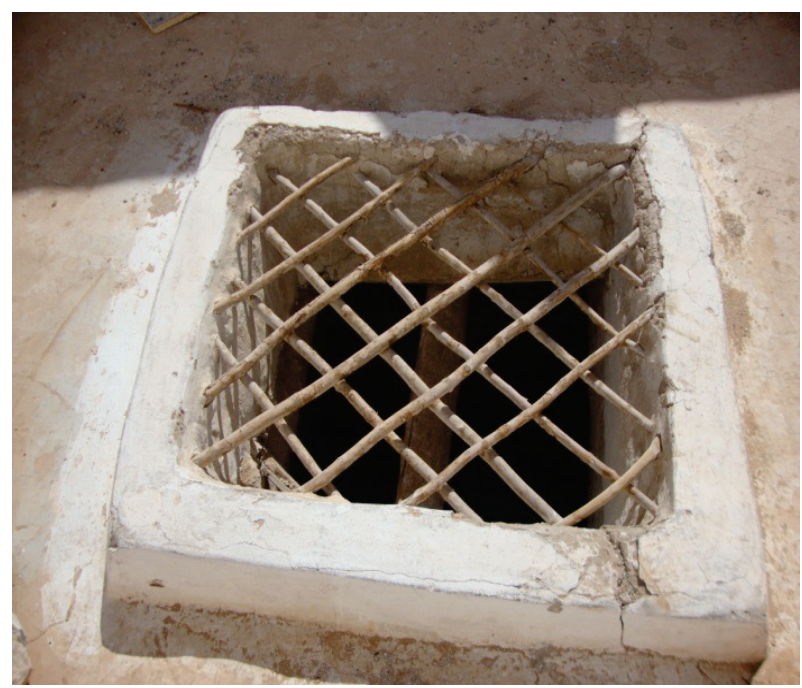

Figures 13 Opening at the roof

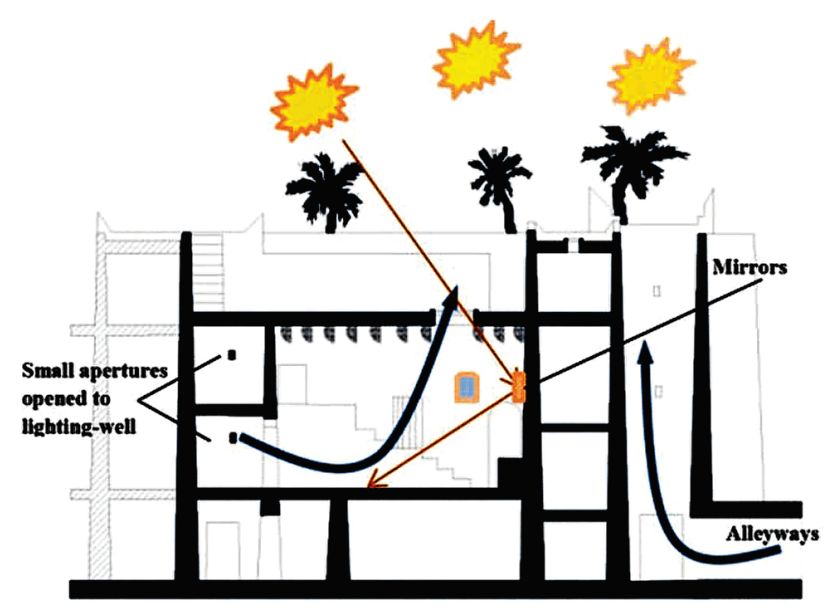

Figures 14 Natural ventilation and lighting in old house [33]

\subsubsection{House organization}

Common spatial design of the old houses in Ghadames represents an outstanding composition of different spaces graduated from fully shaded rooms on the ground level to exposed spaces on the top floor, such as the kitchen. Usually, the house consists of three stories, as shown in Figs. 15 and 16. The entrance is the main place in the house, used for reaching the interior rooms of the house and its dimensions are $0.95 \times 1.80 \mathrm{~m}$. The salon for men with storage zone mostly for agricultural tools or commercial goods is on the ground floor. The central hall (living room), with dimension $5 \mathrm{~m} \mathrm{x} 6 \mathrm{~m}$ is located on a mezzanine level with a number of bedrooms. Some rooms are large dimensions $2.17 \times 7 \mathrm{~m}$, while the others are small dimensions $1.60 \times 3.90 \mathrm{~m}$ on the first floor. Finally, the upper floor is containing the kitchen and summer shed. The kitchen is placed on the roof to increase mutual shading and also to dispose of heat and smoke outside the house. Majority of houses stand wall-to-wall on four sides, with adjacent houses leaving small courts to light up the alleyways and encourage air movement to ventilate internal spaces. Through the uppermost aperture in the ceiling of the living room there are porous and blind shutters used to shut or open this void depending on 
outdoor climate conditions. Mirrors and hanging metalcrafts are used in the living room to reflect and increase the amount of light into surrounding rooms. Most houses in Ghadames are of the same design, differing only in their size and decoration depending on the economic circumstances of the families living in them [33].

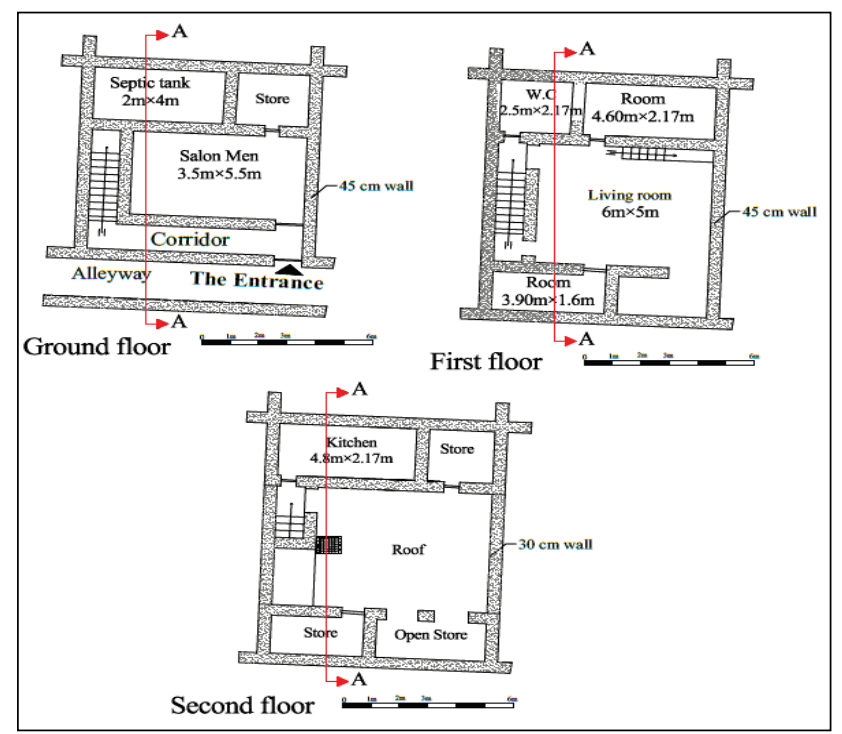

Figure 15 Plan of the house in Ghadames

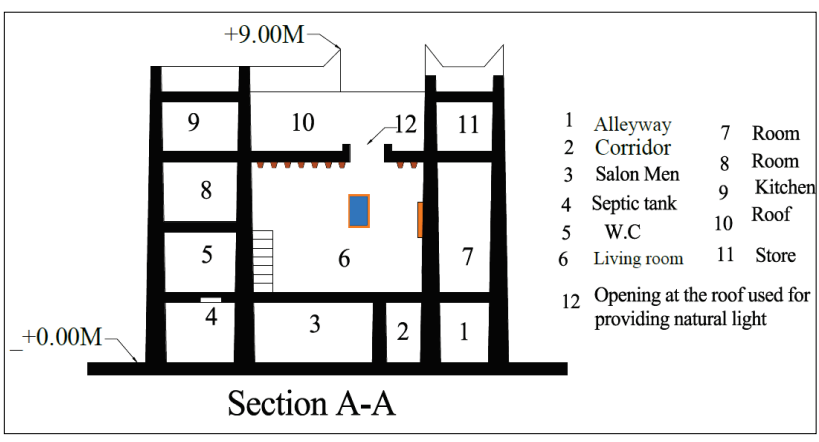

Figure 16 Section (A-A) of the house in Ghadames

\subsubsection{Thermal comfort}

The mean annual temperature outside the analysed house is approximately $45{ }^{\circ} \mathrm{C}$. In July, the temperature inside the house is about $29{ }^{\circ} \mathrm{C}$, while in January the temperature is only $11.2{ }^{\circ} \mathrm{C}$ inside the house, while outside it is approximately $7^{\circ} \mathrm{C}$. The parameters measured in this study were air temperature outdoors and indoors. Figs. 17 and 18 present hourly dry-bulb temperatures measured during January in winter and during July in summer, 2014. Also we conclude in Figs. 17 and 18 that the majority readings of indoor temperature for the traditional house are approximately constant during the day in summer and in winter, and were within the range for human comfort in this zone. That is because of many reasons such as old houses adopted in such a technique using local masonry materials with thick walls and roofs up to $70 \mathrm{~cm}$. The properties of these constructional materials and the way they were constructed effectively work as a bioclimatic thermal modifier. In addition, these materials are well treated before use in construction, such as maintaining the mixture of moulding mud bricks for a few weeks and sun drying. The wood extracted from palm trees was also treated to ensure its sustainability and avoid late invasion by insects. Old houses were built using a bearing wall system. On the ground floor, the walls are $60 \div 70 \mathrm{~cm}$ thick and gradually decrease in thickness on the first and second floors, approximately $40 \mathrm{~cm}$ on the top floor.

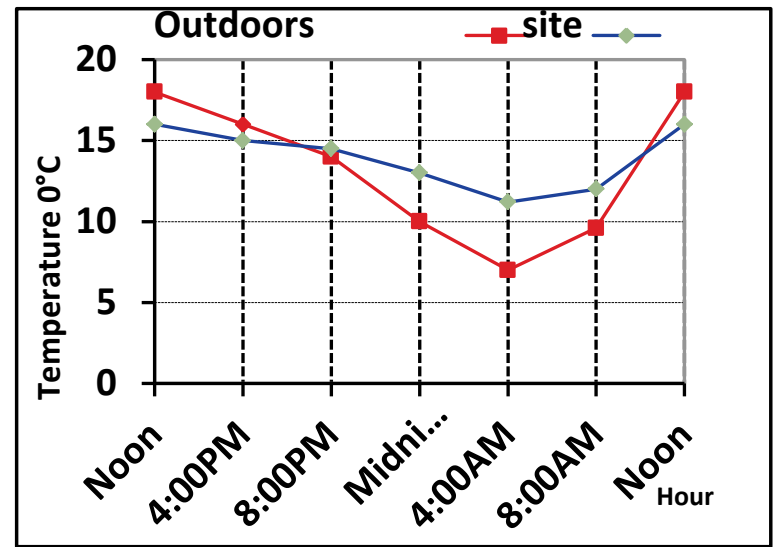

Figure 17 Temperature data for Ghadames during one day in January

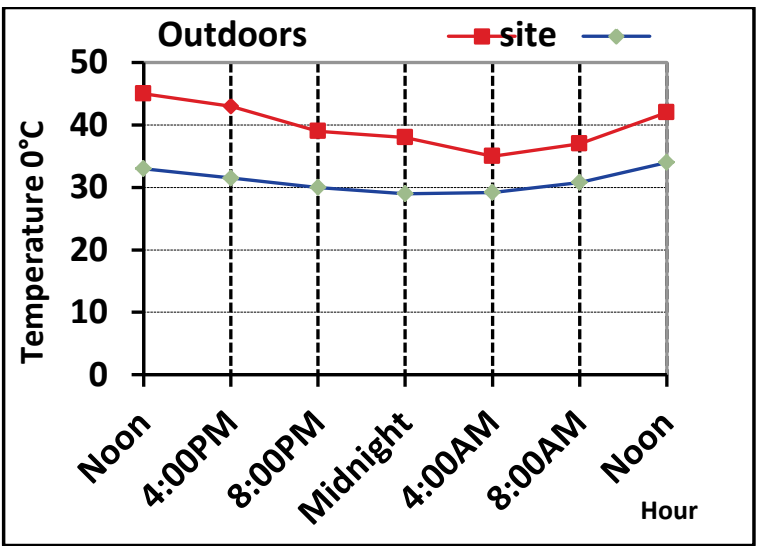

Figure 18 Temperature data for Ghadames during one day in July

\section{Conclusion}

Study examines the aspects of thermal comfort and adaptability in vernacular single family houses, showing that the traditional architecture in North Africa and the Arab world is built according to the influences of culture, climate and terrain of those regions. The researchers came across some important and valuable conclusions, as follows:

Mountain region (Gharyan): The underground dwelling is characterized by the central courtyard as the basic element of the house. This type of house is known for the suitability to environmental conditions that are cold in winter and warm in summer. In other word, the temperature is similar to the temperature of the ground. Field measurements indicated that the troglodyte dwellings provide more comfortable environment in this region throughout the year. As a result of the study of this house, we can determine several things: the simplicity of the shapes reflects the interest for the functionality rather than architecture, the structural system does not depend on construction materials, construction of the house greatly relies on human labour employed in digging the clay, and also one room is considered to be like the whole house. The underground dwelling, or the troglodyte, 
represents a case of the optimal exploitation of the allenvironmental possibilities.

Desert region (Ghadames): Traditional Libyan house in this region leans on the vertical design; it also relies on the local building materials that have a function to make the house more suitable to the climate. That high temperature leads to the consideration of the "closed design", where the dominating style is the compressed system, in order to create a shelter against the extreme climate through deep, twisted and narrow streets, this means that the construction is shadowed by walls and ceilings in order to be cool and comfortable, even during the hottest part of the day. That architectural design in traditional houses shows how social life is valued, especially at the privacy level, where women mainly use the upper floor paths to comfortably move around buildings. Additionally, there are not many openings that face the outside. The external walls have a general appearance of light colours due to the brownish and pale yellow walls made of sun-dried clay bricks, top capping of the walls and stepped finials at the corners are whitewashed, providing a characteristic feature to the external appearance of the houses. These pale and light colours are of effective impression; likewise, they improve the thermal performance of the building envelope to extreme climate conditions, light colours are the best reflecting surfaces, because their reflectivity is about $75 \div 85 \%$, so they reflect most of the solar radiation that strikes the surface, minimizing thermal loads on the outside surfaces and improving the microclimate inside the house.

The results show that the vernacular optimal houses are more suited to the climate and for achieving Aspects of thermal comfort and adaptability in it. That courtyard is the feature which is prevalent in traditional Libyan architecture in both rural and urban areas, presenting an effective way to build a home, as well as to create an acceptable inside environment, also it acts as a modification in hot, dry area, allowing residents to be outside with the protection from sun, dust and wind, the presence of plants and water fountains inside the courtyard helps hydrate the internal atmosphere. The courtyard is used for cooking, gatherings, social activities, festive celebrations, resting, bringing light to otherwise dark areas of the house, and for catching the breeze.

The strategy of building traditional houses in two regions of Libya presumes the use of natural materials that are underused, especially nowadays. It is similar to the strategy for achieving adaptability. Thus, the outcomes of this study would benefit architects in producing building designs that would promote human comfort, social-cultural sustainability, and occupant preferences while minimizing energy consumption using passive design strategies learned from the vernacular architecture. From these findings, it is evident that social and physical environmental determinants coincide, thus enhancing sustainable housing and total adaptability to the site and culture.

\section{Acknowledgments}

We would like to express our deepest gratitude to the assistance of local people in two regions in Libya, Gharyan and Ghadames, who provided us with some important and very helpful information about their houses, construction materials, structural systems, some samples of measurements of the temperature inside and outside of old houses, lifestyle and social interaction, and the entrenched identity of the locally built environment.

\section{References}

[1] Krpo, M. Open space typology of residential buildings in Ottoman civilization. // Tehnički vjesnik. 22, 6(2015), pp. 1505-1509.

[2] Reynolds, J. Libyan Studies: Select Papers of the late R.G. Goodchild. London: Paul Elek, 1976.

[3] Edwards, B.; Sibley, M.; Land, P.; Hakmi, M. Courtyard Housing Past, Present \& Future. New York: Taylor \& Francis, 2006.

[4] Larice, M.; Macdonald, E. The urban design reader. New York: Routledge, 2013.

[5] Sharifi, A.; Murayama, A. Changes in the traditional urban form and the social sustainability of contemporary cities: A case study of Iranian cities. // Habitat International. 38(2013), pp. 126-134. https://doi.org/10.1016/j.habitatint.2012.05.007

[6] Benevolo, L. Grad u istorijiEvrope. Beograd: Clio, 2004.

[7] Poropat, A. Optimization model for family house plot elements - the Istria case. // Tehnički vjesnik. 21, 1(2014), pp. 199-205.

[8] Uysal, M. M.; Uysal, M. Urban growth simulation using sleuth in Afyonkarahisar (Turkey). // Tehnički vjesnik. 22, 5(2015), pp. 1255-1261.

[9] Ali-Toudert, F. Dependence of outdoor thermal comfort on street design. // PhD Thesis. University of Freiburg, Freiburg, 2005.

[10] Ali-Toudert, F.; Mayer, H. Numerical study on the effects of aspect ratio $\mathrm{H} / \mathrm{W}$ and orientation of an urban street canyon on outdoor thermal comfort. // Building and environment. 41, 2(2006), pp. 94-108. https://doi.org/10.1016/j.buildenv.2005.01.013

[11] Imamoglu, V. Microclimatic elements of homes in Turkish arid zones. // Housing in Arid Lands: Design and Planning, ed. Golany G. / London: The Architectural Press, 1980, pp. 45- 74.

[12] Meir, I. A.; Bennett Mackenzie, J.; Roaf, S. C. Learning from the past - shaping the future. Combining archaeology and simulation tools to teach building physics and appropriate solutions. // Renewable Energy for a Sustainable Development of the Built Environment, Proceedings of the 18th PLEA International Conference / Florianopolis, 2001, pp. 951-956.

[13] Szockolay, S. Thermal design of houses for warm-humid climates. // Building and Urban Renewal, Proceedings of the 13th PLEA International Conference / Louvain-laNeuve, 1996.

[14] Koenigsberger, O. H.; Ingersoll, T. G.; Mahyew, A.; Sokolay, S. V. Manual of tropical housing and building. London: Lorgman, 1973.

[15] Golany, G. Design for arid regions. New York: Van Nostrand Reinhold, 1982.

[16] Golany, G. Urban design morphology and thermal performance. // Atmospheric Environments. 30(1996), pp. 455-465. https://doi.org/10.1016/1352-2310(95)00266-9

[17] Givoni, B. Climate considerations in building and urban design. New York: Van Nostrand Reinhold, 1997.

[18] Saini, B. S. Building in Hot Dry Climates. Brisbane: John Wiley, 1980.

[19] World Atlas of Desertification. U. N. Environment Program // eds. Middleton, N.; Thomas, D. / London: Arnold, 1997.

[20] Ealiwaa, M. A.; Takia, A. H.; Howarthb, A. T.; Sedena, M. $\mathrm{R}$. An investigation into thermal comfort in the summer 
season of Ghadames, Libya. // Building and Environment. 36, 2(2001), pp. 231-237. https://doi.org/10.1016/S0360-1323(99)00071-2

[21] Ahmad, Khetrish, E.; Abughres, S. M. Thermal analysis of the architecture of old and new houses at Ghadames. // Building and Environment, 20, 1(1985), pp. 39-42. https://doi.org/10.1016/0360-1323(85)90029-0

[22] Ali-Toudert, F.; Djenane, M.; Bensalem, R.; Mayer, H. Outdoor thermal comfort in the old desert city of BeniIsguen, Algeria. // Climate Research, 28(2005), pp. 243256. https://doi.org/10.3354/cr028243

[23] Meier, I. A.; Roaf, S. C.; Gileard, I.; Runsheng, T.; Stavi, I.; Mackenzie-Bennett, J. The vernacular and the environment towards a comprehensive research methodology. // Proceedings of the 21st International Conference Passive and Low Energy Architecture / Eindhoven, 2004, pp. 719724.

[24] National Physical Perspective plans. // Ministry of Municipalities. Tripoli, Libya, 1979.

[25] Aburroush, M. A. Cross-Cultural Study of Locus of Control and Self-Esteem as Related to Socio cultural Factors among Libyan and British Postgraduate Student. // PhD Thesis. The University of Manchester, UK, 1996.

[26] Grifa, M. The Construction Industry in Libya, with particular reference to operations in Tripoli. // $\mathrm{PhD}$ Thesis. University of Newcastle upon Tyne, UK, 2006.

[27] Encyclopaedic World Atlas. London: Philip's, 2000.

[28] Elwefati, N. A. Bio-climate architecture in Libya: Case studies from three climatic regions. // MSc Dissertation. Middle East Technical University, Ankara, Turkey, 2007.

[29] Warfalli, M. Some Islamic Monuments in Jabal-Nafousa. // PhD Thesis, University of London, 1981.

[30] El-Agouri, F. A. Privacy And Segregation as A Basis For Analyzing and Modelling The Urban Space Composition of The Libyan Traditional City Case Study: The City of Ghadames. // PHD Dissertation. Middle East Technical University, 2004.

[31] Al-Zubaidi, M. S. The efficiency of thermal performance of the desert buildings - the traditional house of Ghadames/Libya. // Proceedings of the Annual Conference of the Canadian Society for Civil Engineering / Montreal, Quebec, 2002, pp. 28-35.

[32] Ealiwa, A. Designing for thermal comfort in naturally ventilated and air-conditioned buildings in the summer season of Ghadames, Libya. // PhD Thesis. Leicester School of Architecture, De Montfort University, Leicester, UK, 2000.

[33] Alabid, J.; Taki, A. Bioclimatic housing design to desert architecture: A case study of Ghadames, Libya. // Hvac \& R Research. 20, 7(2014), pp. 760-769. https://doi.org/10.1080/10789669.2014.953872

\section{Authors' addresses}

Abdrahman Shahran, PhD student

University of Novi Sad, Faculty of Technical Sciences, Department of Architecture and Urbanism

Trg D. Obradovica 6, 21000 Novi Sad, Serbia

shahran_82@yahoo.com

Darko Reba, PhD, associate professor

University of Novi Sad, Faculty of Technical Sciences, Department of Architecture and Urbanism

Trg D. Obradovica 6, 21000 Novi Sad, Serbia

rebad@uns.ac.rs

Milena Krklješ, PhD, associate professor

University of Novi Sad, Faculty of Technical Sciences, Department of Architecture and Urbanism

Trg D. Obradovica 6, 21000 Novi Sad, Serbia

mkrkljes@uns.ac.rs 